\title{
Faktor-Faktor yang Mempengaruhi Fraud Pemerintah Daerah: Peran Intervening Perilaku Tidak Etis
}

\author{
*Dewi Septiningsih $1,{ }^{* *}$ Saiful Anwar ${ }^{2}$ \\ ${ }^{1,2}$ Institut Agama Islam Negeri Salatiga
}

\begin{tabular}{ll}
\hline ARTICLE INFO & ABSTRACT \\
\hline $\begin{array}{l}\text { Article History: } \\
\text { Received: 15 May 2021 }\end{array}$ & $\begin{array}{l}\text { This study aims to analyze the perceptions of employees in government } \\
\text { agencies regarding the effect of effectivity of internal control, } \\
\text { compensation suitability, information asymmetry and individual morality } \\
\text { on fraud with unethical behavior as an intervening variable in Boyolali } \\
\text { regional government. The population of this study consisted of } 1.862 \\
\text { employees and the research sample was 101 employees of government } \\
\text { agencies by using purposive sampling method. The results of this study } \\
\text { indicate that the effectiveness of internal control and suitability of } \\
\text { compensation has no effect on fraud. Information asymmetry and } \\
\text { individual morality have a significant negative effect on fraud. While } \\
\text { unethical behavior has a significant positive effect on fraud. Then the } \\
\text { effectiveness of internal control and individual morality does not have a } \\
\text { significant effect on unethical behavior. Furthermore, the suitability of } \\
\text { compensation and information asymmetry has a significant positive effect } \\
\text { on unethical behavior. The results of the path analysis show that unethical } \\
\text { behavior can mediate the effect of suitability of compensation and } \\
\text { information asymmetry on fraud. However, it cannot mediate the effect of } \\
\text { effectivity of internal control and individual morality on fraud. This } \\
\text { research can be used by public sector management to determine fraud } \\
\text { prevention strategies in the government. }\end{array}$ \\
$\begin{array}{l}\text { Effectiveness of Internal Control, } \\
\text { Suitability of Compensation, }\end{array}$ \\
$\begin{array}{l}\text { Morality, Fraud, Unethical } \\
\text { Behavior }\end{array}$
\end{tabular}

\begin{abstract}
ABSTRAK
Penelitian ini bertujuan untuk menganalisis persepsi pegawai di instansi pemerintahan mengenai pengaruh keefektifan pengendalian internal, kesesuaian kompensasi, asimetri informasi, dan moralitas individu terhadap fraud dengan perilaku tidak etis sebagai variabel intervening di Pemerintah Daerah Boyolali. Populasi penelitian ini terdiri dari 1.862 pegawai dan sampel penelitian sejumlah 101 pegawai instansi pemerintah dengan menggunakan metode purposive sampling. Hasil penelitian ini menunjukkan pengaruh keefektifan pengendalian internal dan kesesuaian kompensasi tidak berpengaruh terhadap fraud. Asimetri informasi dan moralitas individu berpengaruh negatif signifikan terhadap fraud. Sedangkan perilaku tidak etis berpengaruh positif signifikan terhadap fraud. Kemudian keefektifan pengendalian internal dan moralitas individu tidak berpengaruh signifikan terhadap perilaku tidak etis. Selanjutnya kesesuaian kompensasi dan asimetri informasi berpengaruh positif signifikan terhadap perilaku tidak etis. Hasil dari path analysis menunjukkan bahwa variabel perilaku tidak etis dapat memediasi pengaruh variabel kesesuaian kompensasi dan asimetri informasi terhadap fraud. Namun, tidak dapat memediasi pengaruh variabel keefektifan pengendalian internal dan moralitas individu terhadap fraud. Penelitian ini dapat dijadikan oleh manajemen sektor publik untuk menetapkan strategi pencegahan fraud pada pemerintah.
\end{abstract} yang Mempengaruhi Fraud Pemerintah Daerah: Peran Intervening Perilaku Tidak Etis. Jurnal Ilmiah Wahana Akuntansi, 16(1), 17-35. https://doi.org/10.21009/ wahana.16.012 


\section{PENDAHULUAN}

Pemerintahan yang baik merupakan suatu prasyarat bagi setiap pemerintahan untuk menjalankan tugasnya dengan efektif dan efisien yang bertujuan untuk mewujudkan cita-cita negara Indonesia. Setiap Organisasi Perangkat Daerah (OPD) memiliki kewajiban untuk membuat akuntabilitas keuangan sebagai bentuk pertanggungjawaban dalam melaksanakan tugas pokok dan fungsinya. Akuntabilitas keuangan adalah bentuk pertanggungjawaban dari masingmasing pemerintahan untuk menyajikan laporan keuangan secara transparan untuk mencapai tujuan yang telah ditentukan. Laporan keuangan yang disajikan merupakan bentuk pertanggungjawaban dari pemerintah kepada seluruh masyarakat mengenai keluar masuknya keuangan yang terjadi dalam instansi pemerintahan. Angka yang tercantum pada laporan keuangan harus menunjukkan keadaan yang terjadi sebenarnya (Dewi \& Ratnadi, 2017).

Salah satu contoh penerapan good governance adalah tingkat fraud yang rendah. Oleh karena itu, keberhasilan pada sistem tata kelola pemerintahan maka dapat mengurangi kecenderungan seseorang untuk melakukan kecurangan dalam pemerintahan. Saat ini, tindakan fraud sebagai suatu permasalahan yang perlu perhatian khusus. Association of Certified Fraud Examiners (ACFE, 2014), menjelaskan bahwa tindakan fraud adalah perbuatan yang melawan hukum dilakukan secara sengaja dengan maksud tertentu seperti kegiatan memanipulasi laporan keuangan, atau memberikan laporan yang keliru kepada pihak lain, kegiatan tersebut dapat dilakukan oleh individu maupun sekelompok orang baik dalam/luar organisasi dengan tujuan untuk mendapatkan keuntungan pribadi maupun kelompoknya yang secara langsung/tidak langsung menimbukan kerugian kepada pihak lain.

Indonesia termasuk negara dengan tingkat korupsi yang tinggi. Transparency International (TI) menghitung dengan cara memberi skor dari 0 (highly corrupt) sampai dengan 100 (very clean). Skor CPI Indonesia pada tahun 2020 adalah 40 poin dan berada di posisi ke 85 dari 180 negara. Skor tersebut hanya naik 2 poin dari tahun 2019. Selanjutnya, dapat diketahui dari Indonesia Corruption Watch (ICW) melalui Tren Penegakan Hukum Kasus Korupsi 2020 ditemukan 169 kasus korupsi yang ditangani penegak hukum dengan jumlah kerugian negara sebesar Rp18,1 triliun, nilai suap sebesar Rp20,2 miliar dan pungutan liar sebesar Rp44,6 miliar. Kasus korupsi tersebut berasal dari jenis kasus penggelapan, mark up, kegiatan/proyek fiktif, laporan fiktif, pungutan liar, penyalahgunaan wewenang, penyalahgunaan anggaran, suap, penyunatan/pemotongan, manipulasi saham, gratifikasi, anggaran ganda dan mark down (www.antikorupsi.org). Melansir dari data Rekapitulasi Tindak Pidana Korupsi oleh KPK, per 1 Juni 2020 KPK melakukan penanganan dari tindakan korupsi antara lain: penyelidikan 78 perkara, penyidikan 43 perkara, penuntutan 40 perkara, inkracht 70 perkara, dan eksekusi 69 perkara (www.kpk.go.id).

Berdasarkan data dari ICW menempatkan Jawa Tengah sebagai provinsi pertama untuk 
kasus korupsi terbanyak selama tahun 2020 dengan 17 kasus dan jumlah kerugian negara sebesar Rp61,4 miliar, di Jawa Tengah tindakan korupsi yang sering dilakukan adalah penggelapan dengan 5 kasus korupsi. Berdasarkan hasil dari pemantauan, Pemerintah Kabupaten merupakan lembaga yang paling banyak terjadi kasus korupsi. Tahun 2020 diketahui terdapat 62 kasus korupsi yang terjadi di Pemerintah Kabupaten dengan jumlah 150 tersangka yang merugikan keuangan negara sebesar Rp64,5 miliar (www.antikorupsi.org).

Selain hal itu, berdasarkan pada Laporan Hasil Pemeriksaan dari BPK atas Laporan Keuangan Pemerintah Kabupaten Boyolali Tahun Anggaran 2019 menyatakan bahwa BPK memberikan pendapat "Wajar Tanpa Pengecualian". BPK menemukan adanya kelemahan pada sistem pengendalian intern atas Laporan Keuangan Pemerintah Kabupaten Boyolali. Kelemahan tersebut adalah penatausahaan persediaan pada RSUD Simo, RSUD Waras Wiris, Puskesmas Cepogo dan DPUPR belum tertib antara lain perencanaan dan pencatatan pengadaan barang untuk persediaan tidak akurat. Selanjutnya, pada pengelolaan aset tetap Pemerintah Kabupaten Boyolali belum sepenuhnya tertib sehingga penyajian aset menjadi kurang informatif dan kurang terjamin keamanan penguasaannya (BPK, 2019).

Penelitian yang menguji tentang keefektifan pengendalian internal dilakukan oleh Rahmi \& Sovia (2017) dan Maulidya \& Fitri (2020) menunjukkan hasil keefektifan pengendalian internal berpengaruh positif signifikan terhadap fraud. Namun berbeda dengan penelitian Adi et al. (2016) dan Rahmah \& Haryoso (2018) yang menerangkan bahwa kefektifan pengendalian internal memiliki pengaruh negatif signifikan terhadap fraud. Kemudian mengenai pengaruh kesesuaian kompensasi terhadap fraud. Penelitian oleh Adi et al. (2016) dan Arthana (2019) menyatakan bahwa kesesuaian kompensasi berpengaruh positif signifikan terhadap fraud. Akan tetapi, berbeda dengan penelitian Permatasari et al. (2017) dan Albar Meurah \& Fitri Aida (2018) menunjukkan kesesuaian kompensasi memiliki pengaruh negatif terhadap fraud. Selanjutnya mengenai pengaruh asimetri informasi terhadap fraud. Penelitian oleh Fitri (2016) dan Rahmah \& Haryoso (2018) membuktikan bahwa asimetri informasi memiliki pengaruh positif signifikan terhadap fraud. Sebaliknya penelitian dari Adi et al. (2016) menunjukkan hasil asimetri informasi berpengaruh negatif dan signifikan terhadap fraud. Kemudian mengenai pengaruh moralitas individu terhadap fraud. Penelitian Yulianti (2016) dan Fitri (2016) menunjukkan hasil moralitas individu berpengaruh positif terhadap fraud. Berbeda dengan penelitian Indriastuti et al. (2016) dan Sudarman \& Kusuma (2019) menunjukkan bahwa moralitas individu berpengaruh negatif signifikan terhadap fraud.

\section{TINJAUAN TEORI \\ Fraud Triangle Theory}

Fraud Triangle Theory dijabarkan oleh Cressey (1953) yang mengemukakan bahwa terdapat tiga faktor yang mempengaruhi fraud yaitu tekanan (pressure), kesempatan (opportunity), 
dan rasionalisasi (rasionalization).

\section{Agency Theory}

Teori keagenan oleh Jensen \& Meckling (1976) digunakan untuk menjelaskan mengenai fraud dalam hal memecahkan dua permasalahan yang terjadi dalam hubungan keagenan. Suatu permasalahan yang sering muncul akibat dari adanya perbedaan kepentingan antara pihak agen dan pihak prinsipal disebut agency problems.

\section{Teori Atribusi}

Teori atribusi telah dikembangkan Kelley (1967) selanjutnya Green \& Mitchell (1979). Teori ini memiliki pandangan bahwa atribut penyebab merupakan akibat dari perilaku kepemimpinan. Fritz (1958) berpendapat bahwa setiap perilaku seseorang dapat ditentukan melalui kombinasi antara kekuatan internal dan kekuatan eksternal.

\section{Teori Perkembangan Moral}

Teori perkembangan moral yang sering digunakan dalam penilaian terhadap etika yaitu model Kohlberg. Kohlberg (1995) menerangkan bahwa perkembangan moral dapat melewati dari tiga tahapan yaitu: tahapan pre-conventional, tahapan conventional, dan tahapan postconventional.

\section{Kerangka Penelitian}

Kerangka konseptual penelitian ini disajikan pada Gambar 1.

\section{Pengembangan Hipotesis}

Ikhsan \& Ishak (2005:55) menerangkan bahwa teori atribusi adalah suatu perbuatan dari pemimpin yang dipengaruhi oleh atribut penyebab. Menurut Yanto, (2017) pengendalian internal perlu dilakukan dengan tujuan untuk mengawasi atau memantau apakah dalam sebuah kegiatan operasional atau finansial dari sebuah organisasi sudah berjalan sesuai pada prosedur dan kebijakan yang telah ditetapkan oleh pihak manajemen. Penelitian Permatasari et al. (2017), Siregar \& Hamdani (2018), dan Rahmah \& Haryoso (2018) menunjukkan bahwa hasil penelitian sistem pengendalian internal berpengaruh negatif signifikan terhadap fraud.

$\mathrm{H}_{1}$ : Keefektifan pengendalian internal berpengaruh negatif terhadap fraud.

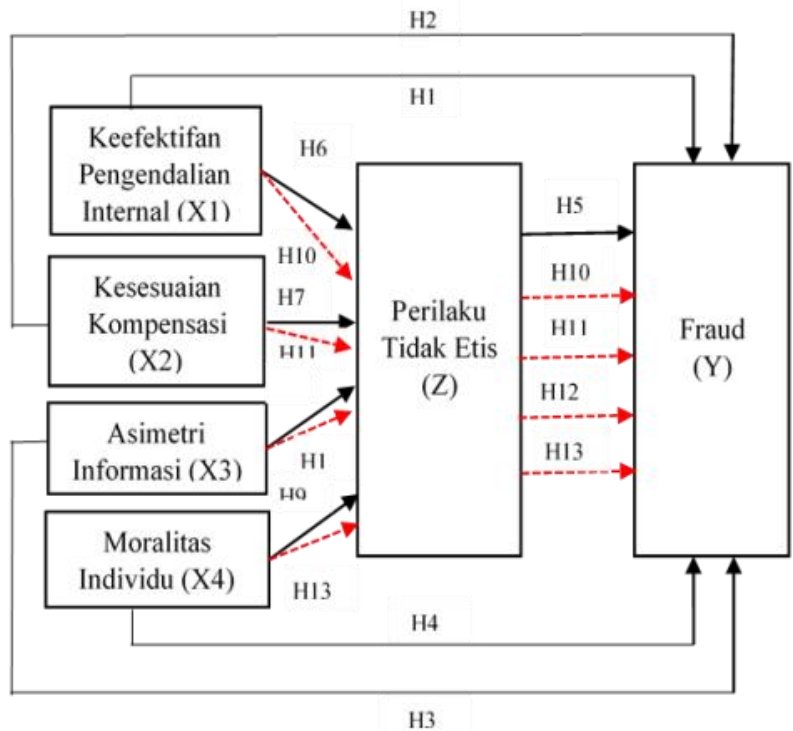

Keterangar:

$\longrightarrow$ Garis pengaruh langsung variabel $\mathrm{X}$ terhadap variabel $\mathrm{Y}$

$\rightarrow$ Garis pengaruh tidak langsung variabel $X$ terhadap variabel $Y$

\section{Gambar 1}

\section{Kerangka Penelitian}

Sumber: Data diolah oleh peneliti, Tahun 2021

Kompensasi berperan penting untuk meningkatkan motivasi karyawan untuk bekerja 
berprestasi sehingga tinggi rendahnya kompensasi akan mempengaruhi kinerja (Permatasari et al., 2017). Penelitian Permatasari et al. (2017), Siregar \& Hamdani (2018) dan Albar Meurah \& Fitri Aida (2018) menunjukkan bahwa kesesuaian kompensasi berpengaruh negatif dan signifikan terhadap fraud.

$\mathrm{H}_{2}$ : Kesesuaian kompensasi berpengaruh negatif terhadap fraud.

Teori keagenan digunakan untuk mencari solusi dari permasalahan mengenai hubungan keagenan. Asimetri informasi dapat menimbulkan konflik dari prinsipal dan agen untuk memanfaatkan pihak lain untuk mengubah informasi dalam penyusunan laporan keuangan sehingga hal tersebut menyebabkan fraud (Wilopo, 2006). Penelitian Fitri (2016), Rahmah \& Haryoso (2018), dan Permatasari et al. (2017) menunjukkan hasil asimetri informasi memberikan pengaruh positif dan signifikan terhadap fraud.

$\mathrm{H}_{3}$ : Asimetri informasi berpengaruh positif terhadap fraud.

Kohlberg (1969) mengelompokkan tahapan penalaran moral yaitu, pra-konvensional, konvensional dan post-konvensional. Welton (1994) menjelaskan bahwa kemampuan dari setiap individu untuk menyelesaikan dilema etika selalu dipengaruhi oleh level penalaran moral. Seseorang dengan penalaran moral tinggi dalam melakukan tindakannya ia lebih memperhatikan lingkungan sekitarnya dan mendasari tindakannya pada prinsip moral yang berlaku. Penelitian Sudarman \& Kusuma (2019) dan Anggreni et al. (2020) menunjukkan hasil moralitas individu memberikan pengaruh negatif signifikan terhadap fraud.

$\mathrm{H}_{4}$ : Moralitas individu berpengaruh negatif terhadap fraud.

Griffin \& Ebert, (2006) menjelaskan bahwa perilaku tidak etis adalah perilaku yang didalamnya tidak sesuai dengan norma sosial yang berlaku di masyarakat. Adanya perilaku tidak etis adalah suatu hal yang sulit untuk ditelaah dan jawabannya dapat diketahui dari interaksi yang kompleks dari pelakunya, suatu perilaku dapat dikatakan tidak etis dapat dilihat dari penyalahgunaan kekuasaan, wewenang, dan sumber daya organisasi. Penelitian Permatasari et al. (2017) dan Arthana (2019) menunjukkan hasil perilaku tidak etis memiliki pengaruh positif signifikan terhadap fraud.

$\mathrm{H}_{5}$ : Perilaku tidak etis berpengaruh positif terhadap fraud.

Efektifitas pengendalian internal adalah keberhasilan yang dicapai oleh manajemen untuk mencapai tujuan organsasi yang berkaitan dengan laporan keuangan yang handal, efisiensi operasional dan ketaatan pada peraturan yang berlaku, adanya pengendalian yang efektif dapat meminimalisir terjadinya fraud (Rahmah \& Haryoso, 2018). Penelitian Shintadevi (2015) menunjukkan hasil keefektifan pengendalian internal berpengaruh negatif signifikan terhadap perilaku tidak etis.

$\mathrm{H}_{6}$ : Keefektifan pengendalian internal berpengaruh negatif terhadap perilaku tidak etis.

Sistem kompensasi yang telah didesain diharapkan dapat memotivasi karyawan untuk bekerja dengan optimal. Maka dari itu, dengan strategi tersebut dapat mengurangi tindakan 
fraud dari pegawai instansi untuk berperilaku tidak etis guna mendapatkan keuntungan pribadi. Penelitian Pratiwi (2016) dan Nurlaeliyah \& Anisykurlillah (2017) menunjukkan hasil dari kesesuaian kompensasi memiliki pengaruh negatif dan signifikan terhadap perilaku tidak etis.

$\mathrm{H}_{7}$ : Kesesuaian kompensasi berpengaruh negatif terhadap perilaku tidak etis.

Kesempatan adalah kondisi yang memungkinkan seseorang untuk melakukan fraud. Penyebab tindakan fraud dikarenakan adanya kesempatan yaitu asimetri informasi (Virmayani et al., 2017). Asimetri informasi yang terjadi antara atasan dan bawahan akan berpengaruh pada laporan keuangan yang akan menyebabkan fraud (Arthana, 2019). Penelitian Nurlaeliyah \& Anisykurlillah menunjukkan asimetri informasi memiliki pengaruh positif signifikan terhadap perilaku tidak etis.

$\mathrm{H}_{8}$ : Asimetri informasi berpengaruh positif terhadap perilaku tidak etis.

Seseorang yang mempunyai moralitas tinggi diharapkan akan bertindak sesuai dengan prinsip moral, namun sebaliknya seseorang yang mempunyai moral yang rendah akan cenderung berperilaku tidak etis. Penelitian (Pratiwi, 2016) menunjukkan hasil negatif dan signifikan terhadap fraud. Maka dari itu, dapat diartikan apabila semakin tinggi tingkat moralitas individu, maka perilaku tidak etis akan semakin rendah.

$\mathrm{H}_{9}$ : Moralitas individu berpengaruh negatif terhadap perilaku tidak etis.

Teori atribusi menjelaskan mengenai perbuatan dari seorang pemimpin yang dipengaruhi oleh atribut penyebab. Oleh karena itu, dengan adanya sistem pengendalian internal yang efektif akan mengurangi perilaku tidak etis. AICPA (1997) menjelaskan bahwa pengendalian internal adalah suatu hal yang penting dengan cara memberikan perlindungan bagi entitas akan kelemahan yang dimiliki manusia dan akan mengurangi tindakan yang tidak sesuai dengan peraturan. Penelitian Bestari (2016) dan Fitri (2016) menunjukkan hasil keefektifan pengendalian internal memiliki pengaruh negatif dan signifikan terhadap fraud melalui perilaku tidak etis.

$\mathrm{H}_{10}$ : Keefektifan pengendalian internal berpengaruh negatif terhadap fraud dengan perilaku tidak etis sebagai pemediasi.

Jika sistem kompensasi tidak sesuai dengan ketentuan yang ditetapkan, maka akan memicu perilaku tidak etis yang dilakukan seseorang dengan tujuan mendapatkan keuntungan yang maksimal. Perilaku tidak etis dapat menimbulkan terjadinya tindakan fraud (Pratiwi, 2016). Penelitian Shintadevi (2015) dan Nurlaeliyah \& Anisykurlillah (2017) menunjukkan kesesuaian kompensasi berpengaruh negatif dan signifikan terhadap fraud dengan perilaku tidak etis sebagai pemediasi.

$\mathrm{H}_{11}$ : Kesesuaian kompensasi berpengaruh negatif terhadap fraud dengan perilaku tidak etis sebagai pemediasi.

Asimetri informasi adalah kondisi dimana terjadi ketidaksamaan dalam memperoleh informasi mengenai kinerja dari agen dan sebaliknya agen tidak mempunyai informasi 
lebih mengenai kapasitas, lingkungan tempat bekerja dan lainnya. Asimetri informasi dapat memicu terjadinya perilaku tidak etis yang mengarah pada tindakan fraud. Penelitian Bestari (2016) dan Fitri (2016) menunjukkan bahwa asimetri informasi memiliki pengaruh positif dan signifikan terhadap fraud melalui perilaku tidak etis sebagai pemediasi.

$\mathrm{H}_{12}$ : Asimetri informasi berpengaruh positif terhadap fraud dengan perilaku tidak etis sebagai pemediasi.

Teori penalaran moral Kohlberg (1995) menjelaskan bahwa pengetahuan mengenai penalaran moral bertujuan untuk mendeteksi sikap setiap individu. Seseorang dengan penalaran moral yang rendah akan memicu perilaku tidak etis yaitu dengan memanfaatkan wewenang yang dimilikinya dengan tujuan mendapatkan keuntungan yang maksimal. Dengan demikian perilaku tidak etis akan meningkatkan tindakan fraud. Penelitian Yulianti (2016) menunjukkan hasil moralitas individu memiliki pengaruh negatif dan signifikan terhadap tindakan fraud dengan perilaku tidak etis sebagai pemediasi.

$\mathrm{H}_{13}$ : Moralitas individu berpengaruh negatif terhadap fraud dengan perilaku tidak etis sebagai pemediasi.

\section{METODE PENELITIAN}

Jenis penelitian ini adalah penelitian kuantitatif. Sumber data yang digunakan adalah jenis data primer, yaitu data yang langsung memberikan informasi kepada pengumpul data. Teknik pengumpulan data dengan metode kuesioner. Kuesioner adalah teknik pengumpulan data yang dilakukan dengan memberikan beberapa pertanyaan atau pernyataan tertulis kepada responden untuk dijawabnya (Sugiyono, 2013:142).

Populasi yang digunakan pada penelitian ini sebanyak 28 Organisasi Perangkat Daerah (OPD) di Kabupaten Boyolali. Jumlah dari populasi pada penelitian ini sebanyak 1.862 orang. Sampel adalah bagian dari jumlah dan karakteristik yang terdapat pada populasi (Sugiyono, 2013:81). Teknik dalam penentuan sampel yang digunakan dengan purposive sampling. Jumlah sampel pada penelitian ini sebanyak 101 responden. Skala pengukuran pada penelitian ini dengan menggunakan skala likert 1-5. Sedangkan waktu penelitian ini dilakukan bulan Februari 2021.

Analisis data pada penelitian ini dengan menggunakan alat statistik regresi linear berganda dengan bantuan software statistik SPSS versi 25. Berikut ini persamaan penelitian yang digunakan:

Persamaan 1

Perilaku Tidak Etis $=\alpha+\beta_{1}$ Keefektifan Pengendalian Internal $+\beta_{2}$ Kesesuaian Kompensasi $+\beta_{3}$ Asimetri Informasi + $\beta_{4}$ Moralitas Individu $+\mathrm{e}$

Persamaan 2

Fraud $=\alpha+\beta_{1}$ Perilaku Tidak Etis $+\beta_{2}$ Keefektifan Pengendalian Internal $+\beta_{3}$ Kesesuaian Kompensasi $+\beta_{4}$ Asimetri Informasi $+\beta_{5}$ Moralitas Individu $+\mathrm{e}$

Definisi operasional variabel yang pertama adalah fraud. Fraud sebagai variabel dependen. Ikatan Akuntan Indonesia (2001) menyatakan bahwa fraud sebagai salah saji dalam laporan keuangan yang memicu tindakan fraud seperti salah saji/ manipulasi data/ 
mengungkapkan laporan keuangan dengan tujuan untuk membohongi para pemakai laporan keuangan. kemudian salah saji pada bentuk perlakuan yang tidak sesuai pada aktiva/ perbuatan penggelapan dengan tujuan untuk melakukan pencurian aktiva sehingga mengakibatkan laporan keuangan tidak sesuai dengan Prinsip Akuntansi yang Berterima Umum (PABU) di Indonesia. Penelitian ini menggunakan indikator dari ACFE, (2014) yang terdiri dari: (1) Kecurangan pada laporan keuangan; (2) Penyalahgunaan aset; dan (3) Korupsi.

Selanjutnya variabel perilaku tidak etis sebagai variabel intervening. Perilaku tidak etis merupakan suatu tindakan yang berlawanan dengan norma sosial yang dapat diterima di lingkungan masyarakat dan memiliki kesinambungan pada tindakan yang mengarah pada hal yang bermanfaat/membahayakan (Griffin \& Ebert, 2006). Penelitian ini menggunakan indikator dari Tang et al., (2003) yang terdiri dari: (1) Penyalahgunaan kedudukan; (2) Penyalahgunaan sumber daya organisasi; (3) Penyalahgunaan kekuasaan; (4) Perilaku tidak berbuat apa-apa; dan (5) Perilaku mengabaikan peraturan.

Kemudian variabel independen yang pertama adalah keefektifan pengendalian internal. Peraturan Pemerintah Nomor 60 Tahun 2008 Tentang Sistem Pengendalian Intern Pemerintah (SPIP) merupakan suatu sistem pengendalian internal yang secara keseluruhan dilakukan baik di lingkungan pusat maupun daerah. Oleh karena itu, untuk memperoleh tujuan pengelolaan keuangan yang transparan dan akuntabel, maka penyampaian laporan keuangan harus tepat waktu untuk mengurangi tindakan penyelewengan dalam menggunakan anggaran belanja. Penelitian ini menggunakan indikator dari Peraturan Pemerintah Nomor 60 Tahun 2008 Tentang Sistem Pengendalian Intern Pemerintah yang terdiri dari: (1) Lingkungan pengendalian; (2) Penilaian mengenai risiko; (3) Kegiatan Pengendalian; (4) Informasi dan komunikasi; dan (5) Pemantauan kegiatan pengendalian internal.

Lalu, variabel independen yang kedua adalah kesesuaian kompensasi. Hariandja (2005) kesesuaian kompensasi adalah suatu bentuk balas jasa yang didapatkan seluruh pegawai sebagai bentuk imbalan dikarenakan telah menyelesaikan pekerjaannya yang dapat berupa uang atau lainnya seperti gaji, bonus, upah dan insentif serta tunjangan lainnya. Penelitian ini menggunakan indikator dari Gibson et al., (2012) yang terdiri dari: (1) Kompensasi keuangan; (2) Pengakuan organisasi atas keberhasilan melaksanakan pekerjaan; (3) Promosi; (4) Penyelesaian tugas; (5) Pencapaian sasaran; dan (6) Pengembangan pribadi.

Selanjutnya, variabel independen yang ketiga adalah asimetri informasi. Asimetri informasi adalah suatu keadaaan yang tidak seimbang antara pihak yang mempunyai informasi dan pihak yang memerlukan informasi (Wilopo, 2006). Penelitian ini menggunakan indikator dari Dunk, (1993) yang terdiri dari: (1) Situasi dimana pihak intern memiliki informasi yang lebih baik atas aktivitas; (2) Situasi dimana pihak intern 
instansi mengetahui hubungan input dan output dalam bagiannya; (3) Situasi dimana pihak intern instansi lebih mengetahui potensi kerja yang telah menjadi tanggungjawabnya; (4) Situasi dimana pihak intern instansi mengetahui teknis pekerjaan dibandingkan dengan pihak luar instansi; (5) Situasi dimana pihak intern instansi lebih mengetahui faktor eksternal dalam bidang yang menjadi tanggungjawabnya dibandingkan pihak ekstern; dan (6) Situasi dimana pihak intern instansi lebih mengerti mengenai apa yang dapat dicapai dalam bidang yang menjadi tanggungjawabnya.

Variabel independen yang terakhir adalah moralitas individu. Santrock, (2002:370) menjelaskan bahwa moralitas individu adalah suatu perilaku yang proporsional dengan tambahan beberapa sikap (keadilan, kejujuran dan penghormatan pada hak dan kebutuhan dari orang lain). Penelitian ini menggunakan indikator dari Kohlberg, (1969) yang terdiri dari: (1) Orientasi kepatuhan sebagai tanggung jawab; (2) Orientasi minat untuk tujuan pribadi; (3) Orientasi antara komunikasi dan tindakan yang berpengaruh pada sosial; (4) Orientasi otoritas untuk memelihara aturan sosial; (5) Orientasi hukum sebagai kontrak sosial; dan (6) Prinsip keadilan dalam bertindak.

\section{HASIL DAN PEMBAHASAN \\ Uji Reliabilitas}

Uji reliabilitas bertujuan untuk mengukur kuesioner apakah handal atau reliabel apabila jawaban dari seseorang pada pernyataan selalu konsisten. Suatu variabel dapat dikatakan reliabel apabila dapat memberikan nilai Cronbach Alpha $>0,60$ (Ghozali, 2018:45).
Hasil uji reliabilitas dari penelitian ini disajikan pada Tabel 1.

Tabel 1

Hasil Uji Reliabilitas

\begin{tabular}{lcc}
\hline \multicolumn{1}{c}{ Variabel } & $\begin{array}{c}\text { Cronbach } \\
\text { Alpha }\end{array}$ & Keterangan \\
\hline $\begin{array}{l}\text { Keefektifan } \\
\text { Pengendalian }\end{array}$ & 0,815 & Reliabel \\
$\begin{array}{l}\text { Internal } \\
\text { Kesesuaian }\end{array}$ & & \\
Kompensasi & 0,786 & Reliabel \\
Asimetri Informasi & 0,934 & Reliabel \\
Moralitas Individu & 0,790 & Reliabel \\
Fraud & 0,883 & Reliabel \\
Perilaku Tidak Etis & 0,795 & Reliabel \\
\hline
\end{tabular}

Sumber: Data diolah oleh peneliti, Tahun 2021

Dari Tabel 1 menunjukkan bahwa seluruh variabel pada penelitian ini memiliki nilai Cronbach Alpha >0,06 yang menunjukkan bahwa seluruh variabel telah reliabel.

\section{Uji Validitas}

Uji validitas digunakan untuk mengetahui apakah kuesioner dapat dinyatakan valid apabila pertanyaan dalam kuesioner mampu untuk mengungkapkan sesuatu yang akan diukur dengan kuesioner tersebut. Uji signifikansi dilakukan dengan membandingkan $r$ hitung dengan $r$ tabel untuk $(d f)=n-2$ (Ghozali, 2018:51). Uji instrumen validitas diperoleh bahwa nilai dari Pearson Correlation untuk setiap item pernyataan lebih besar dari 0,1956 maka dapat disimpulkan setiap item pernyataan dalam kuesioner valid.

\section{Uji Normalitas}

Uji normalitas digunakan untuk mengetahui apakah dalam suatu model regresi, antara variabel bebas dan variabel terikat memiliki distribusi yang normal atau justru terjadi 
sebaliknya. Teknik yang digunakan untuk mendeteksi yaitu dengan uji KolmogorovSmirnov (K-S) yaitu jika nilai dari signifikansi Asymp. Sig. (2-tailed) > 0,05 maka hasil tersebut menunjukkan bahwa data terdistribusi normal (Ghozali, 2018:161).

Hasil uji normalitas dari penelitian ini disajikan pada Tabel 2.

Tabel 2

Hasil Uji Normalitas

\begin{tabular}{lr}
\hline & $\begin{array}{c}\text { Unstandardized } \\
\text { Residual }\end{array}$ \\
\hline $\mathrm{N}$ & 101 \\
Kolmogorov-Smirnov Z & 0,083 \\
Asymp. Sig. (2-tailed) & 0,081 \\
\hline
\end{tabular}

Sumber: Data diolah oleh peneliti, Tahun 2021

Tabel 2 di atas dapat diketahui bahwa nilai dari test statistic Kolmogrov-Smirnov (K-S) adalah 0,083 dan niai Asymp. Sig. (2-tailed) adalah 0,081. Berdasarkan pada hasil dari uji normalitas diketahui nilai signifikansi 0,081 > 0,05. Maka dapat disimpulkan bahwa nilai residual berdistribusi normal.

\section{Uji Multikolinearitas}

Uji multikolinearitas bertujuan untuk mengetahui apakah dalam model regresi dapat ditemukan adanya korelasi antar variabel independen. Apabila nilai dari Variance Inflation Factor (VIF) tidak lebih dari angka 10 dan nilai dari tolerance tidak kurang dari 0,1 maka dalam model tersebut dapat dikatakan bebas dari adanya multikolinearitas (Ghozali, 2018:107).

Hasil uji multikolinearitas dari penelitian ini disajikan pada Tabel 3.

Pada Tabel 3 menunjukkan bahwa nilai VIF untuk setiap variabel bebas yang terdiri dari kefektifan pengendalian internal, kesesuaian kompensasi, asimetri informasi dan moralitas individu adalah lebih kecil dari 10,0. Nilai tolerance untuk setiap variabel juga lebih besar dari 0,1. Dengan demikian, maka dapat disimpulkan bahwa setiap variabel bebas tidak terjadi multikolinearitas.

Tabel 3

\section{Hasil Uji Multikolinearitas}

\begin{tabular}{lcc}
\hline \multicolumn{1}{c}{ Variabel } & \multicolumn{2}{c}{ Collinearity Statistics } \\
& Tolerance & VIF \\
\hline $\begin{array}{l}\text { Keefektifan } \\
\begin{array}{l}\text { Pengendalian } \\
\left(\mathrm{X}_{1}\right)\end{array}\end{array}$ Internal & 0,782 & 1,278 \\
$\begin{array}{l}\text { Kesesuaian } \\
\text { Kompensasi }\left(\mathrm{X}_{2}\right)\end{array}$ & 0,712 & 1,404 \\
$\begin{array}{l}\text { Asimetri Informasi }\left(\mathrm{X}_{3}\right) \\
\text { Moralitas Individu }\left(\mathrm{X}_{4}\right)\end{array}$ & 0,822 & 1,216 \\
\hline
\end{tabular}

Sumber: Data diolah oleh peneliti, Tahun 2021

\section{Uji Heteroskedastisitas}

Uji heteroskedastisitas bertujuan untuk menguji apakah dalam model regresi terjadi ketidaksamaan varian residual dari suatu pengamatan terhadap pengamatan yang lainnya.

Pada penelitian ini menggunakan uji glesjer untuk mendeteksi permasalahan heteroskedastisitas yaitu dengan mentransformasikan nilai residual menjadi nilai absolut residual dan selanjutnya melakukan regresinya dengan variabel bebas. Apabila signifikansi dari variabel bebas $>0,05$, maka dapat disimpulkan bahwa tidak terdapat gejala heteroskedastisitas (Ghozali, 2018:137).

Hasil uji heteroskedastisitas dari penelitian ini disajikan pada Tabel 4.

Hasil dari pengolahan data pada Tabel 4, maka dapat disimpulkan bahwa variabelvariabel pada penelitian ini tidak terjadi 
terjadi heteroskedastisitas dikarenakan nilai signifikansinya $>0,05$.

Tabel 4

Hasil Uji Heteroskedastisitas

\begin{tabular}{lc}
\hline \multicolumn{1}{c}{ Variabel } & Sig. \\
\hline Konstanta & 0,396 \\
Keefektifan Pengendalian Internal $\left(\mathrm{X}_{1}\right)$ & 0,108 \\
& \\
Kesesuaian Kompensasi $\left(\mathrm{X}_{2}\right)$ & 0,229 \\
Asimetri Informasi $\left(\mathrm{X}_{3}\right)$ & 0,516 \\
Moralitas Individu $\left(\mathrm{X}_{4}\right)$ & 0,644 \\
\hline Sumber: Data diolah oleh peneliti, Tahun 2021 &
\end{tabular}

\section{Uji Linearitas}

Uji linearitas bertujuan untuk mengetahui apakah pada 2 (dua) variabel memiliki hubungan yang linear/tidak secara signifikan. Apabila nilai signifikansi dari deviation from linearity lebih besar dari 0,05 maka dapat disimpulkan bahwa data tersebut adalah linear (Ghozali, 2018:167).

Hasil uji linearitas dari penelitian ini disajikan pada Tabel 5.

\section{Tabel 5}

\section{Hasil Uji Linearitas}

\begin{tabular}{llcc}
\hline $\begin{array}{c}\text { Variabel } \\
\text { Dependen }\end{array}$ & $\begin{array}{c}\text { Variabel } \\
\text { Independen }\end{array}$ & $\begin{array}{c}\text { Sig. Deviation } \\
\text { from Linearity }\end{array}$ & Keterangan \\
\hline Fraud & $\begin{array}{l}\text { Keefektifan } \\
\text { Pengendalian }\end{array}$ & 0,329 & Linear \\
& $\begin{array}{l}\text { Internal }\left(\mathrm{X}_{1}\right) \\
\text { Kesesuaian }\end{array}$ & 0,065 & Linear \\
& $\begin{array}{l}\text { Kompensasi } \\
\left(\mathrm{X}_{2}\right)\end{array}$ & & \\
& $\begin{array}{l}\text { Asimetri } \\
\text { Informasi }\left(\mathrm{X}_{3}\right)\end{array}$ & 0,474 & Linear \\
& $\begin{array}{l}\text { Moralitas } \\
\text { Individu }\left(\mathrm{X}_{4}\right)\end{array}$ & 0,869 & Linear \\
\hline
\end{tabular}

Sumber: Data diolah oleh peneliti, Tahun 2021

Hasil uji linearitas pada Tabel 5 dapat disimpulkan bahwa nilai signifikansi deviation from linearity seluruh variabel adalah $>0,05$ maka menunjukkan hubungan antara masingmasing variabel terhadap fraud adalah linear.

\section{Uji Koefisien Determinasi $\left(\mathbf{R}^{2}\right)$}

$\mathrm{R}^{2}$ bertujuan untuk mengukur mengenai seberapa jauhnya dalam suatu model dapat menjelaskan variasi dari variabel terikat. Koefisien Determinasi dapat dihitung dengan $\mathrm{R}^{2}$ yang mempunyai nilai antara 0-1 dengan syarat semakin mendekati 1 maka akan semakin baik (Bawono, 2006).

Hasil uji koefisien determinasi dari penelitian ini disajikan pada Tabel 6 .

Tabel 6

Hasil Uji Koefisien Determinasi

\begin{tabular}{crr}
\hline Model & R Square & \multicolumn{1}{c}{ Adjusted R Square } \\
\hline 1 & 0,312 & 0,276 \\
\hline
\end{tabular}

Sumber: Data diolah oleh peneliti, Tahun 2021

Nilai dari $\mathrm{R}^{2}$ yang terdapat pada Tabel 6 adalah sebesar 0,312 berarti bahwa ada hubungan yang kuat antara variabel bebas terhadap variabel terikat dikarenakan nilai tersebut mendekati angka 1. Adjusted $\mathrm{R}^{2}$ sebesar 0,276 berarti kontribusi dari variabel bebas yang mempengaruhi variabel terikat sebesar $27,6 \%$ sedangkan sisanya sebesar $72,4 \%$ dipengaruhi oleh variabel lainnya yang tidak termasuk dalam penelitian ini.

\section{Uji F}

Uji $F$ dapat digunakan untuk menunjukkan apakah pada semua variabel bebas yang telah dimasukkan ke dalam model memiliki pengaruh secara simultan terhadap variabel terikat (Ghozali, 2018).

Hasil uji $\mathrm{F}$ dari penelitian ini disajikan pada Tabel 7.

Hasil uji $F$ hitung yang disajikan pada Tabel 7 diketahui sebesar 8,625 dengan nilai 
signifikansi $0,000<0,05$, maka dapat disimpulkan bahwa variabel keefektifan pengendalian internal, kesesuaian kompensasi, asimetri informasi, dan moralitas individu secara bersama-sama memiliki pengaruh positif signifikan terhadap fraud.

\section{Tabel 7}

Hasil Uji F

\begin{tabular}{ccc}
\hline Model & F Hitung & Sig. \\
\hline Regression & 8,625 & 0,000 \\
\hline
\end{tabular}

Sumber: Data diolah oleh peneliti, Tahun 2021

\section{Uji T}

Uji T digunakan untuk menjelaskan sejauh mana mengenai hubungan antara variabel bebas terhadap variabel terikat. Cara pengukurannya adalah dengan membandingkan antara nilai $t$ hitung dan nilai $t$ tabel. Jika nilai $t$ hitung $>$ nilai $t$ tabel dengan tingkat signifikansi $<0,05$ maka dapat dikatakan hipotesis alternatif diterima yang menyatakan bahwa variabel bebas secara individual berpengaruh terhadap variabel terikat (Ghozali, 2018).

Hasil uji $\mathrm{T}$ untuk Persamaan 1 dan Persamaan 2 disajikan pada Tabel 8 dan Tabel 9.

Tabel 8

\section{Hasil Uji T - Persamaan 1}

\begin{tabular}{|c|c|c|c|}
\hline Variabel & $\begin{array}{c}\text { Unstandardizied } \\
\text { Coeficients (B) }\end{array}$ & $\begin{array}{c}\mathrm{T} \\
\text { Hitung }\end{array}$ & Sig. \\
\hline Konstanta & 15,643 & 6,737 & 0,000 \\
\hline Keefektifan & \multirow[t]{3}{*}{0,128} & \multirow[t]{3}{*}{1,189} & \multirow[t]{3}{*}{0,237} \\
\hline Pengendalian & & & \\
\hline Internal $\left(X_{1}\right)$ & & & \\
\hline Kesesuaian & \multirow[t]{2}{*}{$-0,058$} & \multirow[t]{2}{*}{$-0,699$} & \multirow[t]{2}{*}{0,486} \\
\hline Kompensasi $\left(\mathrm{X}_{2}\right)$ & & & \\
\hline Asimetri & \multirow[t]{2}{*}{$-0,089$} & \multirow[t]{2}{*}{$-2,017$} & \multirow[t]{2}{*}{0,047} \\
\hline Informasi $\left(\mathrm{X}_{3}\right)$ & & & \\
\hline Moralitas & \multirow[t]{2}{*}{$-0,114$} & \multirow[t]{2}{*}{$-2,240$} & \multirow[t]{2}{*}{0,027} \\
\hline Individu $\left(\mathrm{X}_{4}\right)$ & & & \\
\hline
\end{tabular}

Tabel 9

Hasil Uji T - Persamaan 2

\begin{tabular}{lrrc}
\hline \multicolumn{1}{c}{ Variabel } & $\begin{array}{c}\text { Unstandardizied } \\
\text { Coeficients (B) }\end{array}$ & $\begin{array}{c}\text { T } \\
\text { Hitung }\end{array}$ & Sig \\
\hline Konstanta & 6,497 & 2,081 & 0,040 \\
$\begin{array}{l}\text { Keefektifan } \\
\text { Pengendalian }\end{array}$ & 0,008 & 0,065 & 0,948 \\
$\begin{array}{l}\text { Internal (X) } \\
\text { Kesesuaian }\end{array}$ & & & \\
$\begin{array}{l}\text { Kompensasi } \\
\left(X_{2}\right)\end{array}$ & 0,225 & 2,437 & 0,017 \\
$\begin{array}{l}\text { Asimetri } \\
\text { Informasi } \\
\text { (X) }\end{array}$ & & & \\
$\begin{array}{l}\text { Moralitas } \\
\text { Individu (X })\end{array}$ & 0,122 & 2,459 & 0,016 \\
Fraud (Y) & & & \\
\hline
\end{tabular}

Sumber: Data diolah oleh peneliti, Tahun 2021

\section{Path Analysis}

Analisis jalur merupakan perluasan dari analisis regresi linear berganda/merupakan analisis regresi dengan tujuan untuk menaksir suatu hubungan kausalitas antar variabel (model casual) yang sebelumnya sudah ditetapkan berdasarkan pada teori (Ghozali, 2018:245).

Hasil Path Analysis dengan menggunakan Sobel Test disajikan pada Tabel 10.

Tabel 10

Path Analysis Menggunakan Sobel Test

\begin{tabular}{lllr}
\hline $\begin{array}{c}\text { Variabel } \\
\text { Independen }\end{array}$ & $\begin{array}{c}\text { Variabel } \\
\text { Intervening }\end{array}$ & $\begin{array}{c}\text { Variabel } \\
\text { Dependen }\end{array}$ & $\begin{array}{c}\text { T } \\
\text { Penelitian }\end{array}$ \\
\hline $\begin{array}{l}\text { Keefektifan } \\
\text { Pengendalian }\end{array}$ & Perilaku & Fraud & 1,14276 \\
Internal & Tidak Etis & & \\
$\begin{array}{l}\text { Kesesuaian } \\
\text { Kompensasi }\end{array}$ & $\begin{array}{l}\text { Perilaku } \\
\text { Tidak Etis }\end{array}$ & Fraud & 3,47668 \\
$\begin{array}{l}\text { Asimetri } \\
\text { Informasi }\end{array}$ & $\begin{array}{l}\text { Perilaku } \\
\text { Tidak Etis }\end{array}$ & Fraud & 2,16391 \\
Moralitas & Perilaku & Fraud & $-0,61050$ \\
Individu & Tidak Etis & & \\
\hline
\end{tabular}

Sumber: Data diolah oleh peneliti, Tahun 2021 
Keefektifan Pengendalian Internal dan Fraud

Keefektifan pengendalian internal tidak berpengaruh terhadap fraud. Artinya, jika keefektifan pengendalian internal suatu pemerintahan baik, maka tidak mempengaruhi fraud dikarenakan tingkat fraud dapat disebabkan oleh faktor kesempatan yang ada dalam pemerintahan. Penelitian ini konsisten dengan penelitian dari Rahmi \& Sovia (2017) menunjukkan hasil variabel keefektifan pengendalian internal tidak berpengaruh terhadap fraud. Oleh sebab itu, maka $\mathrm{H}_{1}$ ditolak.

\section{Kesesuaian Kompensasi dan Fraud}

Kesesuaian kompensasi tidak berpengaruh signifikan terhadap fraud. Artinya semakin rendah tingkat kesesuaian kompensasi yang diberikan kepada pegawai maka tidak memberikan pengaruh terhadap fraud, dikarenakan tingkat fraud yang tinggi dapat disebabkan adanya tekanan yang terdapat pada pegawai pemerintahan. Penelitian oleh Permatasari et al. (2017) dan Siregar \& Hamdani (2018) menunjukkan hasil kesesuaian kompensasi tidak memiliki pengaruh terhadap fraud. Sehingga, dari penjelasan di atas maka $\mathrm{H}_{2}$ ditolak.

\section{Asimetri Informasi dan Fraud}

Asimetri informasi memiliki pengaruh negatif dan signifikan terhadap fraud. Artinya semakin tinggi tingkat asimetri informasi yang terjadi di instansi pemerintahan, maka akan menurunkan kecenderungan pegawai untuk melakukan tindakan fraud. Hasil penelitian ini konsisten dengan penelitian Adi et al. (2016) menunjukkan hasil asimetri informasi berpengaruh negatif signifikan terhadap fraud. Berdasarkan pada penjelasan di atas maka $\mathrm{H}_{3}$ ditolak.

\section{Moralitas Individu dan Fraud}

Moralitas individu memiliki pengaruh negatif dan signifikan terhadap fraud. Artinya, semakin tinggi tingkat moralitas pegawai instansi pemerintahan, maka akan menurunkan kecenderungan dari seseorang untuk bertindak fraud dengan tujuan untuk mendapatkan keuntungan pribadi. Seseorang yang mempunyai penalaran moral rendah mempunyai kecenderungan untuk melakukan sesuatu hal yang akan menguntungkan untuk pribadinya. Hasil penelitian ini konsisten dengan hasil penelitian oleh Indriastuti et al. (2016), dan Anggreni et al. (2020) menunjukkan hasil moralitas individu memiliki pengaruh yang negatif dan signifikan terhadap fraud. Artinya semakin tingginya moralitas individu yang ada pada seseorang maka tindakan fraud akan semakin menurun. Dengan demikian, dari penjelasan di atas maka $\mathrm{H}_{4}$ diterima.

\section{Perilaku Tidak Etis dan Fraud}

Perilaku tidak etis berpengaruh positif signifikan terhadap fraud. Artinya, semakin tinggi perilaku tidak etis oleh pegawai, maka akan meningkatkan sikap pegawai untuk melakukan fraud. Hasil penelitian ini sesuai dengan teori atribusi yang menjelaskan mengenai perilaku dari seseorang terhadap suatu peristiwa yang berada di sekitarnya dan dapat mengetahui sebab mengapa melakukan 
melakukan perilaku tersebut. Hasil penelitian ini konsisten dengan penelitian Rahmah \& Haryoso (2018) yang menunjukkan hasil perilaku tidak etis memiliki pengaruh yang positif dan signifikan terhadap fraud. Berdasarkan penjelasan di atas, maka $\mathrm{H}_{5}$ diterima.

\section{Keefektifan Pengendalian Internal dan Perilaku Tidak Etis}

Keefektifan pengendalian internal tidak berpengaruh signifikan terhadap perilaku tidak etis. Maka, dapat diartikan semakin tingginya tingkat keefektifan pengendalian internal dalam instansi pemerintahan maka tidak mempengaruhi kecenderungan seseorang untuk melakukan perilaku tidak etis namun terdapat faktor lain seperti lingkungan dari instansi pemerintahan yang dapat mempengaruhi signifikan. Penelitian ini konsisten dengan penelitian Natalia \& Pranoto (2018) yang menunjukkan hasil penelitian bahwa variabel keefektifan pengendalian internal tidak berpengaruh terhadap perilaku tidak etis. Oleh karena itu, maka $\mathrm{H}_{6}$ ditolak.

\section{Kesesuaian Kompensasi dan Perilaku Tidak Etis}

Kesesuaian kompensasi memiliki pengaruh positif signifikan terhadap perilaku tidak etis. Sistem kompensasi telah direncanakan sebelumnya sehingga diharapkan dapat mendorong pegawai untuk bekerja dengan optimal. Penelitian ini sejalan dengan penelitian Pratiwi (2016) menunjukkan hasil dari kesesuaian kompensasi memiliki pengaruh yang positif signifikan terhadap perilaku tidak etis.
Semakin tinggi tingkat kesesuaian kompensasi yang diberikan maka akan meningkatkan perilaku tidak etis dalam instansi pemerintahan. Sehingga, dari penjelasan di atas maka $\mathrm{H}_{7}$ ditolak.

\section{Asimetri Informasi dan Perilaku Tidak Etis}

Asimetri informasi memiliki pengaruh positif signifikan terhadap perilaku tidak etis. Hal tersebut merupakan salah satu contoh dari perilaku tidak etis yang dilakukan dalam pemerintahan. Perilaku tidak etis yang dengan sengaja dilakukan oleh para pegawai pemerintahan untuk melakukan tindakan fraud menyebabkan kerugian yang harus ditanggung oleh instansi. Penelitian ini konsisten dengan penelitian Bestari (2016) dan Fitri (2016) menunjukkan asimetri informasi memiliki pengaruh positif signifikan terhadap perilaku tidak etis. Artinya semakin tinggi tingkat asimetri informasi yang terjadi, maka akan meningkatkan pula perilaku tidak etis dari pegawai pemerintahan. Oleh karena itu, maka $\mathrm{H}_{8}$ diterima.

\section{Moralitas Individu dan Perilaku Tidak Etis}

Moralitas individu tidak berpengaruh signifikan terhadap perilaku tidak etis. Artinya semakin rendah moralitas dari setiap pegawai, maka tidak memberikan pengaruh terhadap perilaku tidak etis, dikarenakan perilaku tidak etis dapat meningkat karena kurang tegasnya dalam memberikan sanksi terhadap seseorang yang melanggar peraturan sehingga pelaku merasa dirinya bebas tanpa ada suatu hal yang menghalanginya untuk melakukan perbuatan 
yang tidak etis. Hasil dari penelitian ini konsisten dengan penelitian Yulianti (2016) menunjukkan bahwa moralitas individu tidak berpengaruh terhadap perilaku tidak etis. Berdasarkan penjelasan di atas, maka $\mathrm{H}_{9}$ ditolak.

\section{Perilaku Tidak Etis, Keefektifan Pengendalian Internal, dan Fraud}

Perilaku tidak etis tidak dapat memediasi pengaruh keefektifan pengendalian internal terhadap fraud. Teori atribusi telah menjelaskan bahwa tindakan dari pemimpin dapat dipengaruhi oleh atribut yang menjadi penyebabnya. Maka dari itu, dengan adanya pengendalian internal yang efektif maka dapat mengurangi perilaku tidak etis. Penelitian ini sejalan dengan penelitian Natalia \& Pranoto (2018) dalam penelitiannya menghasilkan bahwa keefektifan pengendalian internal tidak memiliki pengaruh terhadap fraud dengan perilaku tidak etis sebagai variabel intervening. Artinya semakin tinggi tingkat keefektifan pengendalian internal di instansi pemerintahan maka tidak mempengaruhi kecenderungan seseorang untuk melakukan fraud melalui perilaku tidak etis. Berdasarkan penjelasan di atas, maka $\mathrm{H}_{10}$ ditolak.

\section{Perilaku Tidak Etis, Kesesuaian Kompensasi, dan Fraud}

Perilaku tidak etis dapat memediasi pengaruh kesesuaian kompensasi terhadap fraud. Sistem kompensasi yang tidak sesuai dengan ketentuan yang telah sepakati, maka dapat menyebabkan seseorang untuk berperilaku tidak etis dengan maksud untuk mendapatkan keuntungan pribadi yang maksimal. Hal ini konsisten dengan penelitian Yulianti (2016) menunjukkan hasil dari variabel kesesuaian kompensasi memiliki pengaruh terhadap fraud dengan perilaku tidak etis sebagai pemediasi. Artinya semakin tinggi tingkat kesesuaian kompensasi yang diperoleh setiap pegawai, maka akan memberikan pengaruh bagi seseorang untuk melakukan kecurangan yang dimediasi oleh perilaku tidak etis. Berdasarkan penjelasan di atas, maka $\mathrm{H}_{11}$ diterima.

\section{Perilaku Tidak Etis, Asimetri Informasi, dan Fraud}

Perilaku tidak etis dapat memediasi pengaruh asimetri informasi terhadap fraud. Adanya asimetri informasi dapat mendorong seseorang untuk berperilaku tidak etis dan melakukan tindakan fraud. Hasil dari penelitian ini konsisten dengan penelitian Bestari (2016) dan Fitri (2016) menunjukkan bahwa variabel asimetri informasi mempunyai pengaruh terhadap fraud melalui perilaku tidak etis sebagai pemediasi. Artinya semakin tingginya suatu asimetri informasi dalam sebuah instansi, maka dapat mempengaruhi seseorang untuk berperilaku tidak etis dan cenderung untuk melakukan fraud yang merugikan berbagai pihak. Berdasarkan penjelasan di atas, maka $\mathrm{H}_{12}$ diterima.

\section{Perilaku Tidak Etis, Moralitas Individu, dan Fraud}

Perilaku tidak etis tidak dapat memediasi pengaruh moralitas individu terhadap fraud. Moralitas secara umum merupakan suatu hal yang pokok dalam melakukan penilaian atas 
suatu tindakan yang dapat diambil dari seseorang. Hasil dari penelitian ini konsisten dengan penelitian Yulianti (2016) bahwa moralitas individu tidak memiliki pengaruh terhadap fraud dengan perilaku tidak etis sebagai variabel intervening. Seseorang dengan penalaran moral yang tinggi tidak memberikan pengaruh terhadap kecenderungan kecurangan akuntansi/ fraud melalui perbuatan yang tidak mengedepankan norma sosial yang dapat diterima oleh masyarakat. Berdasarkan penjelasan di atas, maka $\mathrm{H}_{13}$ ditolak.

\section{KESIMPULAN DAN SARAN}

Berdasarkan pembahasan diatas, maka dapat diambil kesimpulan: Hasil penelitian ini menunjukkan pengaruh variabel keefektifan pengendalian internal dan kesesuaian kompensasi tidak berpengaruh terhadap fraud. Selanjutnya asimetri informasi dan moralitas individu berpengaruh negatif signifikan terhadap fraud. Lalu, perilaku tidak etis berpengaruh positif signifikan terhadap fraud. Selanjutnya keefektifan pengendalian internal dan moralitas individu tidak berpengaruh signifikan terhadap perilaku tidak etis. Sedangkan kesesuaian kompensasi dan asimetri informasi berpengaruh positif signifikan terhadap perilaku tidak etis. Hasil dari path analysis menunjukkan bahwa variabel perilaku tidak etis dapat memediasi pengaruh variabel kesesuaian kompensasi dan asimetri informasi terhadap fraud. Namun, tidak dapat memediasi pengaruh variabel keefektifan pengendalian internal dan moralitas individu terhadap fraud.

Saran bagi peneliti selanjutnya diharapkan untuk memilih variabel-variabel yang dapat memberikan pengaruh pada variabel dependen dan untuk menambahkan variabel budaya etis organisasi dan love of money serta menambahkan metode wawancara dengan tujuan untuk memperoleh hasil penelitian yang lebih menunjukkan keadaan yang sebenarnya.

\section{DAFTAR PUSTAKA}
ACFE. (2014). Report To The Nations On Occuptional Fraud And Abuse.

Adi, M. R. K., Ardiyani, K., \& Ardianingsih, A. (2016). Analisis Faktor-Faktor Penentu Kecurangan (Fraud) pada Sektor Pemerintahan (Studi Kasus pada Dinas Pendapatan Pengelolaan Keuangan dan Aset Daerah Kota Pekalongan). In Jurnal Litbang Kota Pekalongan (Vol. 10, pp. 110).

AICPA. (1997). Consideration of Fraud in a Financial Statement Audit. AU Section 316 PCAOB Standards and Related Rules. New York, NY: AICPA.

Albar Meurah, T., \& Fitri Aida, F. (2018). Pengaruh Komitmen Organisasi, Etika Organisasi, Keadilan Kompensasi, dan Sistem Pengendalian Internal terhadap Fraud (Studi Empiris Pada SKPD Pemerintah Kota Lhokseumawe). In Jurnal Ilmiah Mahasiswa Ekonomi Akuntansi (JIMEKA) (Vol. 3, Issue 3, pp. 527-537).

Anggreni, N. N. S., Sujana, E., \& Julianto, I. P. (2020). Pengaruh Kepuasan Kerja, Kecerdasan Spiritual, dan Moralitas Individu terhadap Kecenderungan Kecurangan (Fraud) (Studi Kasus pada Bank Perkreditan Rakyat di Kabupaten Buleleng). Jurnal Ilmiah Akuntansi Dan Humanika, 10(1), 32-41.

Arthana, I. K. (2019). Analisis Faktor-Faktor Terjadinya Kecurangan (Fraud) dalam Pengelolaan Dana Desa pada Kecamatan Amabi Oefeto Timur. Jurnal Akuntansi: 
Transparansi Dan Akuntabilitas, 7(1), 3543.

Bawono, A. (2006). Multivariate Analysis dengan SPSS. STAIN Salatiga Press.

Bestari, D. S. (2016). Pengaruh Keefektifan Sistem Pengendalian Internal, Ketaatan Akuntansi, Asimetri Informasi dan Moralitas Individu terhadap Kecenderungan Kecurangan Akuntansi dengan Perilaku Tidak Etis sebagai Variabel Intervening (Studi Empiris pada Satuan Kerja Perangkat). JOM Fekon, 3(1), 1436-1447.

BPK. (2019). Laporan Hasil Pemeriksaan Atas Laporan Keuangan Pemerintah Daerah Kabupaten Boyolali Tahun 2019.

Cressey, D. (1953). Other People's Money: a Study in the Social Psychology of Embezzlement. In Glencoe, IL: Free Press.

Dewi, K. Y. K., \& Ratnadi, N. M. D. (2017). Pengaruh Pengendalian Internal dan Integritas pada Kecenderungan Kecurangan Akuntansi Satuan Kerja Perangkat Daerah Kota Denpasar. E-Jurnal Akuntansi Universitas Udayana, 18(2), 917-941.

Dunk. (1993). The Effect of Budget Emphasis and Information Asymmetry on the Relation between Budgetary Participation and Slack. The Accounting Review, 400-410.

Fitri, Y. (2016). Pengaruh Keefektifan Sistem Pengendalian Internal, Ketaatan Akuntansi, Asimteri Informasi dan Moralitas Individu terhadap Kecenderungan Kecurangan Akuntansi dengan Perilaku Tidak Etis sebagai Variabel Intervening. JOM Fekon, 3 (Februari), 505-519.

Fritz, H. (1958). The Psychology of Interpersonal Relations. New York: Wiley.

Ghozali, I. (2018). Aplikasi Analisis Multivariate Dengan Program IBM SPSS 25 Edisi 9. Universitas Diponegoro.

Gibson, L, J., Ivancevich, J., Donnelly, J., \& Konopaske, R. (2012). Organisations: Behavior, Structure, Processes (Fourteenth). New York: Mcgrawhill.
Green, \& Mitchell. (1979). Attributional Processes of Leaders in Leader-Member Interaction. Organizational Behavior and Human Perfomance.

Griffin, R., \& Ebert, R. J. (2006). Bisnis (Edisi Kede). Jakarta: Erlangga.

Hariandja, M. T. E. (2005). Manajemen Sumber Daya manusia. Grasindo.

Ikatan Akuntan Indonesia. (2001). Pertimbangan Atas Kecurangan Dalam Audit Laporan Keuangan". Standar Pemeriksaan Akuntan Publik. SA Seksi 316.

Ikhsan, A., \& Ishak, M. (2005). Akuntansi Keperilakuan. Salemba Empat.

Indriastuti, D. E., Agusdin, \& Animah. (2016). Analisis Pengaruh Asimetri Informasi, Pengendalian Internal, Persepsi Kesesuaian Kompensasi, Moralitas Individu, dan Ketaatan Aturan Akuntansi terhadap Kecurangan Akuntansi. Jurnal InFestasi, 12(Desember), 115-130.

Jensen, \& Meckling, W. H. (1976). Theory of The Firm: Managerial Behaviour, Agency Costs and Ownership Structure. Journal of Financial Economics, 3(305-360).

Kelley. (1967). Attribution Theory in Social Physcology. Nebraka Symposium on Motivation, D. Levine. Lincoln: University of Nebraska Press.

Kohlberg, L. (1969). Stage and sequence: The cognitive-development approach moral action to socialization. In D. A. Goslin $(E d)$. Handbook of socialization theory and research. Chicago: RandMcNally, 347 -480 .

Kohlberg, L. (1995). Tahap-tahap Perkembangan Moral. Yogyakarta: Penerbit Kanisius.

Maulidya, Z., \& Fitri, Y. (2020). Pengendalian Internal terhadap Kecenderungan Kecurangan Akuntansi (Studi Empiris pada Bank Umum Syariah di Kota Banda 
Aceh) Jurnal Ilmiah Mahasiswa Ekonomi Akuntansi (JIMEKA), 5(1), 127-136.

Natalia, E. Y., \& Pranoto, S. B. (2018). Efektivitas Pengendalian Intern dan Kesesuaian Kompensasi terhadap Kecenderungan Kecurangan Akuntansi dengan Perilaku Tidak Etis sebagai Variabel Intervening pada Perusahaan di Kota Batam. Jurnal Akuntansi Barelang, 3(1), 32-42.

Nurlaeliyah, S., \& Anisykurlillah, I. (2017). Analysis of Factors Affecting the Tendency of Accounting Fraud with an Ethical Behavior as Intervening Variable. Accounting Analysis Journal, 6(2), 299312. https://doi.org/10.15294/aaj.v6i2.16892

Peraturan Pemerintah Nomor 60 Tahun 2008 tentang Sistem Pengendalian Intern Pemerintah, 1 (2008).

Permatasari, D. E., Kurrohman, T., \& Kartika. (2017). Analisis Faktor-Faktor yang Mempengaruhi Terjadinya Kecenderungan Kecurangan (Fraud) di Sektor Pemerintah (Studi pada Pegawai Keuangan Pemerintah Kabupaten Banyuwangi). In Jurnal Keuangan Perbankan (Vol. 14, Issue 1, pp. 37-44).

Pratiwi, T. (2016). Pengaruh Penegakan Peraturan, Sistem Kompensasi, Ketaatan Aturan Akuntansi dan Moralitas Aparat terhadap Kecenderungan Kecurangan Akutansi dengan Perilaku Tidak Etis sebagai Variabel Intervening serta Pengaruhnya terhadap Kinerja Instansi Pemerintah. JOM Fekon, 3(1), 2327-2341.

Rahmah, R. N., \& Haryoso, P. (2018). Pengaruh Moralitas Individu, Efektifitas Pengendalian Internal, Asimetri Informasi, Ketaatan Aturan Akuntansi, dan Perilaku Tidak Etis terhadap Kecenderungan Kecurangan Akuntansi. In E-Journal STIE AUB (Vol. 5, Issue 2, pp. 33-41).

Rahmi, F., \& Sovia, A. (2017). Dampak Sistem Pengendalian Internal, Prilaku Tidak Etis, dan Moralitas Manajemen terhadap Kecenderungan Kecurangan Akuntansi pada Perusahaan Developer di Pekanbaru. In
Jurnal Al-Iqtishad (Vol. 13, Issue 1, p. 48). https://doi.org/10.24014/jiq.v13i1.4388

Santrock, J. W. (2002). Life-Span Development Perkembangan Masa Hidup. Erlangga.

Shintadevi, P. F. (2015). Pengaruh Keefektifan Pengendalian Internal, Ketaatan Aturan Akuntansi dan Kesesuaian Kompensasi terhadap Kecenderungan Kecurangan Akuntansi dengan Perilaku Tidak Etis sebagai Variabel Intervening. Jurnal Nominal, 4(2). https://doi.org/10.21831/ nominal.v4i2.8003

Siregar, M. I., \& Hamdani, M. (2018). Pengaruh Kesesuaian Kompensasi, Keefektifan Sistem Pengendalian Internal, Budaya Organisasi, dan Kompetensi Terhadap Fraud. Jurnal Ekonomi Global Masa Kini Mandiri, 9(2), 30-37.

Sudarman, \& Kusuma, S. Y. (2019). Individual Morality To Accounting Fraud Tendency At Whole BMTs In Kudus. International Journal of Scientific and Technology Research, 8(12), 1889-1892.

Sugiyono. (2013). Metode Penelitian Kuantitatif Kualitatif dan R\&D. Bandung: Alfabeta.

Tang, Chen, \& Sutarso. (2003). Income, Money Ethic, Pay Satisfaction, Commitment and Unethical Behavior: Is the Love of Money the Root of Evil for Hong Kong Employees? In Journal of Business Ethics (Vol. 46).

Virmayani, P. C., Sulindawati, N. L. G. E., \& Atmadja, A. T. (2017). Budaya Etis Organisasi dan Komitmen Organisasi terhadap Pencegahan Kecurangan (Fraud) Akuntansi pada Koperasi Simpan Pinjam Se-Kecamatan. E-Journal SI Ak Universitas Pendidikan Ganesha, 1(3).

Welton, D. (1994). "Promoting The Moral Development Of Accounting Graduate Students" Accounting Education. International Journal, 3. 
Wilopo. (2006). Analisis Faktor-Faktor yang Berpengaruh terhadap Kecenderungan Kecurangan Akuntansi: Studi pada Perusahaan Pubik dan Badan Usaha Milik Negara di Indonesia. Simposium Nasional Akuntansi 9.

www.antikorupsi.org/id. (n.d.).

www.kpk.go.id. (n.d.). kpk.go.id.

Yanto, R. R. (2017). Analisis Penerapan Sistem Pengendalian Intern sebagai Risk Control System Pembiayaan di BMT Ramadana. Skripsi.

Yulianti, D. F. (2016). Pengaruh Moralitas Individu, Penegakan Hukum, Keadilan Distributif, Keadilan Prosedural terhadap Kecenderungan Kecurangan Akuntansi dengan Perilaku Tidak Etis sebagai Variabel Intervening. JOMFekom, 4(1), 1960-1970 